\title{
Characterization of Topiary (top) an Architectural Mutant of Common Bean
}

\author{
N. Guner ${ }^{1}$ and J.R. Myers ${ }^{2}$ \\ Department of Horticulture, Oregon State University, Corvallis, OR 97331
}

\begin{abstract}
ADDiTIONAL INDEX wORDs. plant breeding, growth habit, determinacy, genetic analysis
Abstract. Plant breeders are interested in developing upright common beans (Phaseolus vulgaris L.) to reduce diseases and permit mechanical harvest, and improve seed quality. Morphological and genetic characteristics of an architectural mutant in common beans were studied. The mutant had shiny, dark green leaves, overlapping leaflets, and short petioles. Branching was nearly absent, resulting in single stemmed plants. Although mutant plants carried $F$ in for indeterminacy, and plants progressed in flowering from lower to higher nodes, the terminal node was reproductive. This represents a new form of determinacy in common bean. Inheritance studies demonstrated that the mutant syndrome was controlled by a single recessive gene. Allelism tests between the mutant and overlapping leaflets $(o l)$, and dark green savoy leaf $(d g s)$ showed that the mutant was not allelic to either locus. The trait was designated as Topiary with the gene symbol top, describing its compact and neat appearance. Linkage was tested between top and growth habit (fin), shiny leaves, crosssectional shape of pods, striped pod $\left(C\right.$ prp $\left.^{s t}\right)$, and pod suture strings. All genes segregated independently. The genetic merit of the Topiary mutant for improving common beans needs to be investigated, especially the value of single stem growth habit combined with an upright plant habit.
\end{abstract}

Plant breeders have been interested in using architectural traits to avoid disease, and to improve grain quality, lodging resistance, and yield (Coyne, 1980). Plant architecture may be critical to success of dry bean cultivars (Phaseolus vulgaris L.) in various cropping systems (Kelly and Adams, 1987). Varieties in the kidney market class are determinate because growers require a bean that matures uniformly and quickly. The indeterminate vine architecture characteristic of small red, pinto, pink and great northern market classes is associated with higher yields compared to determinate types (Myers, 1992). Growers in the western United States have used cultivars with a floppy vine (type III) habit because these types produce the highest yields, and upright architecture is not needed to avoid foliar diseases. Midwestern growers have greater foliar disease problems, and have preferred upright short vine cultivars that sacrifice some yield potential, but avoid disease. A prostrate growth habit creates considerably more risk of harvest losses from white mold [Sclerotinia sclerotiorum (Lib.) de Bary] (Kelly and Adams, 1987), and Coyne (1980) suggested that severity of white mold could be reduced considerably by developing dry edible beans that have an upright architecture with porous canopy.

Upright plant architecture allows use of direct harvest systems with narrow row spacing, high plant populations, and a flat planting surface. Narrower rows and higher plant populations cause pods to form higher on the plant and allow better competition with weeds. Compared to traditional production systems, less energy is used when direct harvest is incorporated (Smith, 1996).

Four principal growth habits were identified by researchers at Centro Internacional de Agricultura Tropical (CIAT) based on

Received for publication 11 Aug. 1999. Accepted for publication 30 June 2000. Oregon Agricultural Experiment Station technical paper 11537. This research is a contribution to the W-150 regional project. From a MS thesis submitted by the senior author, who was supported by a scholarship from the Turkish Ministry of Education. The cost of publishing this paper was defrayed in part by the payment of page charges. Under postal regulations, this paper therefore must be hereby marked advertisement solely to indicate this fact.

${ }^{1}$ Present address: Department of Horticultural Science, Box 7609, North Carolina State University, Raleigh, NC 27695-7609.

${ }^{2}$ To whom reprint requests should be addressed. determinate or indeterminate habit, number of nodes, internode length, climbing ability, and degree and type of branching. Growth habits are Type I, determinate bush; Type II, indeterminate short vine; Type III, indeterminate prostrate nonclimbing vine; and Type IV, indeterminate climbers (Fernandez, et al. 1986). Another growth habit category not included in this classification is the determinate climber (Debouck et al., 1988). The mutant trait described herein affects plant architecture. The objectives of this study were to perform a genetic analysis of the mutant trait, including inheritance, linkage, and allelism studies, and to characterize the morphology of the mutant.

\section{Materials and Methods}

The mutant line used in this study was first observed and selected in 1995 in the small red (dry bean) breeding line 611413 from the cross 'UI 35'//'NW 59'/92001 by J.R. Myers at the University of Idaho (UI) Kimberly Research and Extension Center, Kimberly, Idaho. UI 35 is a small red bean cultivar released in 1959 by the UI (LeBaron, 1959). NW 59 is also a small red cultivar developed by the USDA-ARS at Prosser, Wash. (Burke, 1982). The breeding line 92001 was used in the UI breeding program, and derived from the cross 'UI 36'/6917 where UI 36 is another small red cultivar (Dean and LeBaron, 1964) and 6917 is a large seeded purple mottled cranberry type breeding line of the Andean center of origin. Seeds from fertile plants with strong expression of the mutant syndrome were harvested to initiate the line. In three generations of self-pollination, the line was stable and true breeding. The four parental lines were chosen to represent different bean types and were crossed to the mutant to study its inheritance. 'Oregon 91G' is a Type I bush blue lake green bean developed at Oregon State University (Baggett et al., 1981). 'Minuette' is a Type I small sieve green bean obtained from Harris Moran Seed Company, Modesto Calif. Genetic stock 5-593, obtained from Mark Bassett, University of Florida, Gainesville, also has a Type I growth habit. 'UI 906' is a Type II upright, early maturing black bean developed in the UI dry bean breeding program (Myers et al., 1991). Table 1 summarizes phenotypic characteristics of the parents used in this study.

Mutant plants were crossed, using standard emasculation 
Table 1. Characteristics of the parents used in a genetic analysis of a mutant in common bean.

\begin{tabular}{|c|c|c|c|c|c|c|c|c|}
\hline Line & $\begin{array}{l}\text { Growth } \\
\text { habit }^{2}\end{array}$ & $\begin{array}{l}\text { Allele at } \\
\text { Fin locus }\end{array}$ & Market class & $\begin{array}{c}\text { Flower } \\
\text { color }\end{array}$ & $\begin{array}{l}\text { Pod cross- } \\
\text { section }\end{array}$ & $\begin{array}{l}\text { Seed } \\
\text { luster }\end{array}$ & $\begin{array}{l}\text { Seed } \\
\text { color }\end{array}$ & $\begin{array}{c}\text { Fiber in } \\
\text { pod suture }\end{array}$ \\
\hline Oregon 91-G & Type I & fin fin & Green bean & White & Round & Dull & White & Absent \\
\hline Minuette & Type I & fin fin & Green bean & White & Round & Dull & White & Absent \\
\hline $5-593$ & Type I & fin fin & Genetic stock & Purple & Flat & Shiny & Black & Present \\
\hline UI-906 & Type II & Fin Fin & Black bean & Purple & Flat & Dull & Black & Present \\
\hline
\end{tabular}

zType I = determinate bush, type II = indeterminate upright short vine.

procedures (Bliss, 1980), with the four parent lines to produce crosses and reciprocals in Spring 1997. $F_{1}$ progeny were grown in the field and greenhouse to produce $\mathrm{F}_{2}$ populations. A total of 576 $\mathrm{F}_{2}$ seeds were planted in a greenhouse in Fall 1997, representing 144 plants per cross, including reciprocals. Data on normal or mutant type and growth habit type were evaluated in these $F_{2}$ populations. The $\mathrm{F}_{2}$ plants were harvested individually when the pods and seeds were dry. All $\mathrm{F}_{3}$ seeds taken from $\mathrm{F}_{2}$ populations were field planted as 576 plots (families) in Summer 1998. In addition, 250 remnant $F_{2}$ seeds from each of eight crosses were planted. Data were collected for normal or mutant type from $\mathrm{F}_{2}$ and $\mathrm{F}_{3}$ populations.

Allelism tests were conducted to determine whether the new mutant was allelic to ol (overlapping leaflets), (Nagata and Bassett, 1984) and dgs (dark green savoy leaves), (Frazier and Davis, 1966). Seeds of genetic stocks PI 583648 carrying ol and PI 583622 with $d g s$ were obtained from the Western Regional Plant Introduction Station, Pullman, Wash. The new mutant was crossed to the $o l$ and $d g s$ stocks in the greenhouse in Spring 1998. Eighteen $F_{1}$ plants of each cross combination and reciprocal were grown in the greenhouse in Summer 1998. Fifty $F_{2}$ plants of each cross combination and reciprocal were planted in the greenhouse in Winter 1999. The $F_{1}$ and $\mathrm{F}_{2}$ populations were evaluated for traits associated with the three mutants, as well as other traits segregating in these crosses.

Chi-square tests for goodness of fit and homogeneity were used to examine segregation ratios in $\mathrm{F}_{2}$ and $\mathrm{F}_{3}$ populations (Mather, 1951; Ramsey and Schafer, 1997). Contingency chi-square test for independence (Everitt, 1977) was used to test for linkage in two point segregation data. The contingency chi-square test of independence makes no prior assumptions about segregation ratios and was the preferred method because inheritance of some traits was not known and/ or some segregation ratios deviated from expected segregation ratios.

\section{Results}

MORPHOLOGICAL DESCRIPTION. We chose Topiary as the designation for the trait because of the resemblance of the mutant to shrubbery from a topiary garden (Fig. 1A). The original genetic background of the mutant is the small red market class with type III indeterminate growth habit, white flowers, medium-sized shiny red seeds, and flat, fibrous, stringy pods. Traits associated with the mutant phenotype include a single stem, dark green leaves that are thicker, smaller, and more brittle than normal leaflets, and determinate growth habit with long internodes. Long internodes and weak stems contribute to a floppy habit.

Fig. 1. The Topiary architectural mutant of common bean. (A) Growth habit of Topiary plants; (B) comparison of Topiary (above) and 'Minuette' (below) leaves showing differences in rachis, petiolule, and petiole lengths (leaflets have been separated from petiole); (C) leaf of the Topiary mutant showing reflexed terminal leaflet compared to the lateral leaflets; and (D) terminal node from a Topiary plant showing inflorescence development, and demonstrating that Topiary is determinate.

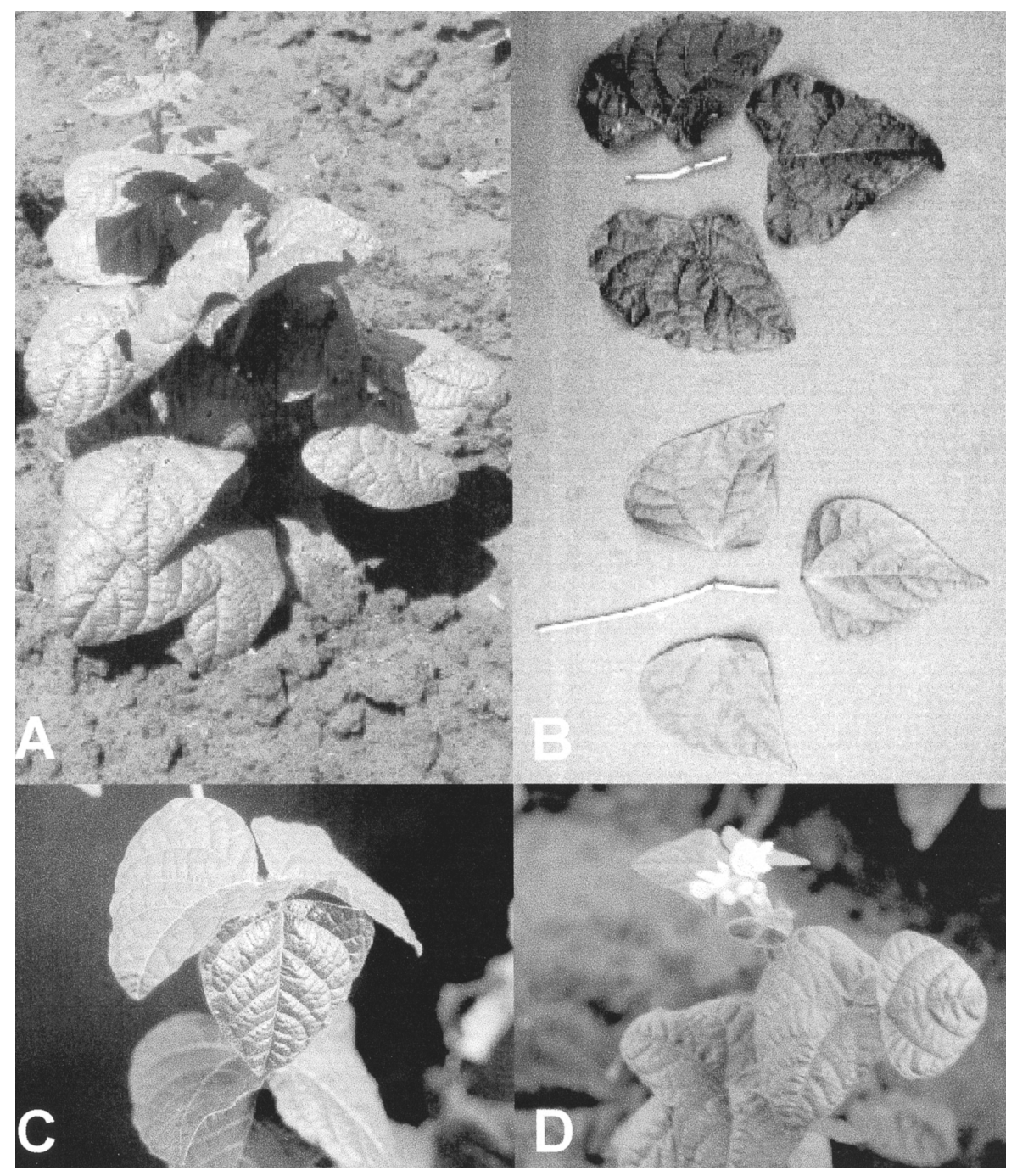


Table 2. $\mathrm{F}_{2}$ segregation data for the Topiary common bean mutant crossed to tester lines and grown in the greenhouse (1997) and at the Oregon State Univ. Vegetable Farm (1998).

\begin{tabular}{|c|c|c|c|c|}
\hline \multirow[b]{2}{*}{$\operatorname{Cross}^{2}$} & \multicolumn{2}{|c|}{ No. of plants } & \multirow[b]{2}{*}{$\chi^{2}(3: 1)$} & \multirow[b]{2}{*}{$P$} \\
\hline & Normal & $\overline{\text { Mutant }}$ & & \\
\hline Topiary mutant x 91G & 213 & 69 & 0.042 & 0.83 \\
\hline $91 \mathrm{G} \times$ Topiary mutant & 205 & 69 & 0.004 & 0.94 \\
\hline Topiary mutant $x$ Minuette & 196 & 61 & 0.219 & 0.63 \\
\hline Minuette $x$ Topiary mutant & 194 & 60 & 0.257 & 0.61 \\
\hline Topiary mutant x 5-593 & 197 & 56 & 1.108 & 0.29 \\
\hline 5-593 $\times$ Topiary mutant & 208 & 66 & 0.121 & 0.72 \\
\hline Topiary mutant x UI 906 & 218 & 68 & 0.228 & 0.63 \\
\hline UI 906 x Topiary mutant & 224 & 71 & 0.136 & 0.71 \\
\hline Combined & 1655 & 520 & 1.383 & 0.23 \\
\hline Homogeneity $^{\mathrm{y}}$ & & & 0.735 & 0.99 \\
\hline
\end{tabular}

${ }^{\mathrm{z}}$ Greenhouse and field populations pooled by cross after chi-square test of homogeneity.

${ }^{\mathrm{y}}$ Homogeneity $\mathrm{df}=7$.

Terminal and lateral leaflets overlap as a result of a shortened rachis and the acute angle of lateral leaf petiolules (Fig. 1B). Lateral petiolules of the mutant averaged $3.0 \pm 0.3 \mathrm{~mm}$ and the rachis averaged $20.0 \pm 0.7 \mathrm{~mm}$ compared to $5.0 \pm 0.3 \mathrm{~mm}$ and 35.0 $\pm 0.8 \mathrm{~mm}$, respectively, for normal leaves of 'Minuette'. The mutant had $36.0 \pm 0.7 \mathrm{~mm}$ petioles compared to $116.0 \pm 1.1 \mathrm{~mm}$ for 'Minuette'. The terminal leaflet pulvinus may be abnormal because the terminal leaflet is sometimes reflexed below the plane of the lateral leaflets (Fig. 1C).

The terminal node is a reproductive bud (Fig. 1D), but unlike determinacy conditioned by fin, the Topiary mutant begins flowering at a lower node, and proceeds up the stem. Whereas plants with fin usually begin flowering at the terminal node, the terminal bud on Topiary is usually the last to open. The Topiary mutant flowers between the 4th and 21st node with time to bloom and node of bloom delayed by increasing daylengths. We do not know if photoperiod sensitivity is a pleiotropic effect of Topiary, or associated with the genetic background of the line.

INHERITANCE. Crosses between Topiary and four normal bean lines produced $F_{1}$ progeny with normal morphology and an indeterminate growth habit, indicating that the mutant trait is recessive. Because '91G', 'Minuette', and 5-593 possess fin, Topiary must have $F$ in. The $\mathrm{F}_{2}$ and $\mathrm{F}_{3}$ segregation data were tested against the expected ratios for a single recessive gene. The $F_{2}$ segregation data obtained from the greenhouse and the field supported an expected 3 normal : 1 mutant ratio (Table 2). The data were homogeneous, indicating that all crosses represented the same population and no differences were observed between the crosses and their reciprocals. These results are consistent with the hypothesis that a single recessive gene controls the Topiary mutant. When $\mathrm{F}_{3}$ families were tested for goodness of fit to an expected 1 normal : 2 segregating: 1 mutant ratio (Table 3 ), the data supported the expected ratio and were homogeneous. Within the segregating families, a 3:1 ratio of normal to mutant plants was observed (Table 3). These data were also homogeneous. The $\mathrm{F}_{3}$ segregation results confirm the hypothesis that a single recessive gene controls the Topiary mutant.

Tests of ALLELISM. Because Topiary might be an allele at the Fin locus, we examined cosegregation of Topiary and fin. Growth habit conditioned by Fin segregated in three of the four crosses'91G', 'Minuette', and 5-593 (Table 4)—but not with 'UI 906' (data not presented). Topiary and fin could be distinguished individually by their distinctive phenotypes. The double recessive plants were small and compact, and exhibited the determinacy pattern of fin with the leaf characteristics of Topiary. Thus, determinacy conditioned by fin appears to be epistatic to that of Topiary. Fin segregated as a single recessive gene and was independent of Topiary (Table 4). There were some apparent disturbances in the segregation ratios. Although one cross (5-593 $x$ Topiary) deviated significantly from the expected ratio (fewer individuals than expected in the double recessive class were observed), the reciprocal fit the expected ratio. Two other crosses ('91G' $x$ Topiary and 'Minuette' $x$ Topiary) had near significant deviations from expected at $P=0.05$. In both cases, more individuals

Table 3. Segregation of $\mathrm{F}_{3}$ families of the Topiary common bean mutant crossed to tester lines grown in 1998.

\begin{tabular}{|c|c|c|c|c|c|}
\hline \multirow[b]{2}{*}{ Cross } & \multicolumn{3}{|c|}{ No. of families } & \multirow[b]{2}{*}{$\chi^{2}(1: 2: 1)$} & \multirow[b]{2}{*}{$P$} \\
\hline & Normal & Segregating $^{z}$ & Mutant & & \\
\hline Topiary mutant x 91G & 17 & 33 & 16 & 0.030 & 0.98 \\
\hline $91 \mathrm{G} \times$ Topiary mutant & 15 & 30 & 21 & 1.636 & 0.44 \\
\hline Topiary mutant $x$ Minuette & 21 & 28 & 14 & 2.284 & 0.31 \\
\hline Minuette $x$ Topiary mutant & 15 & 30 & 14 & 0.050 & 0.97 \\
\hline Topiary mutant x 5-593 & 23 & 33 & 10 & 5.121 & 0.07 \\
\hline 5-593 x Topiary mutant & 21 & 29 & 20 & 2.085 & 0.35 \\
\hline Topiary mutant x UI 906 & 17 & 31 & 17 & 0.138 & 0.93 \\
\hline UI 906 x Topiary mutant & 18 & 24 & 21 & 3.857 & 0.14 \\
\hline Combined & 147 & 238 & 133 & 4.162 & 0.12 \\
\hline Homogeneity $^{\mathrm{y}}$ & & & & 11.041 & 0.68 \\
\hline
\end{tabular}

${ }^{\mathrm{z}}$ Segregation within segregating families fit a 3:1 ratio (3271 normal:1146 mutant, $\chi^{2}=2.104, P=0.14$; homogeneity $\left.\chi^{2}=3.723, \mathrm{df}=7, P=0.81\right)$. yHomogeneity $\mathrm{df}=7$. 
Table 4. Test of independence for Topiary and Fin in an $\mathrm{F}_{2}$ population of common bean.

\begin{tabular}{|c|c|c|c|c|c|c|}
\hline \multirow[b]{2}{*}{ Cross } & \multicolumn{4}{|c|}{ No. of plants } & \multirow[b]{2}{*}{$\chi^{2}$} & \multirow[b]{2}{*}{$P$} \\
\hline & Normal Fin-- & Normal finfin & Topiary Fin-- & Topiary finfin & & \\
\hline Topiary mutant $\times 91 \mathrm{G}$ & 38 & 12 & 10 & 7 & 1.842 & 0.17 \\
\hline $91 \mathrm{G} \times$ Topiary mutant & 37 & 10 & 12 & 9 & 3.357 & 0.06 \\
\hline Topiary mutant $\mathrm{x}$ Minuette & 30 & 22 & 5 & 7 & 1.011 & 0.31 \\
\hline Minuette $\mathrm{x}$ Topiary mutant & 35 & 11 & 7 & 7 & 3.478 & 0.06 \\
\hline Topiary mutant x 5-593 & 43 & 14 & 8 & 5 & 1.034 & 0.30 \\
\hline $5-593 \times$ Topiary mutant & 36 & 15 & 20 & 1 & 5.229 & 0.02 \\
\hline Combined $^{\mathrm{z}}$ & 219 & 84 & 62 & 36 & 2.867 & 0.09 \\
\hline Homogeneity $^{y}$ & & & & & 13.084 & 0.02 \\
\hline
\end{tabular}

${ }^{\mathrm{z}}$ Segregation of fin fits a $3: 1$ ratio $\left(\chi^{2}=2.51, \mathrm{df}=3, P=0.11\right)$.

y Homogeneity $\mathrm{df}=5$.

than expected in the double recessive class were observed. An apparent systematic deviation when Topiary is the male in crosses is an artifact stemming from the use of contingency chi-square to test for independence of the traits (Table 4). When fit to a 9:3:3:1 ratio, these systematic deviations disappear. Overall, homogeneity chisquare was statistically significant, not permitting pooling of the data. The deviations were not consistent with the hypothesis of linkage, and the causes of these deviations are unknown.

Phenotypically, ol and $d g s$ share some features of the Topiary mutant. Topiary and $d g s$ both had dark green glossy leaves whereas Topiary and $o l$ had overlapping leaflets. Expression of overlapping leaflets was less extreme for $o l$ under Oregon greenhouse conditions compared to Topiary. The $o l$ and $d g s$ mutants showed normal growth habit and determinacy conditioned by fin, compared to the distinctive architecture of Topiary. All $\mathrm{F}_{1} \mathrm{~s}$ from crosses of Topiary with $o l$ and $d g s$ produced progeny with normal phenotype with regard to the mutant traits. The $\mathrm{F}_{1}$ progeny also exhibited a combination of traits (normal leaves, indeterminate climbing habit, and purple flowers) not found in either parent indicating that the progeny were the results of hybridization and not self-pollination. In the $\mathrm{F}_{2}$, we were able to distinguish three phenotypic classes (normal, Topiary, and $o l$ or $d g s$ ), but did not observe individuals in the double recessive class. (Table 5). Populations were small but should have been sufficient to detect the double recessive.

LiNKAGE. Independent gene segregation was tested between Topiary and flower color $(V$ and $P)$, pod color $\left(C\right.$ prp $\left.^{\text {st }}\right)$, pod crosssectional shape (oligogenic inheritance), shiny leaves (genetic control unknown), and pod suture strings (oligogenic inheritance). The test of allelism between top and fin reported above also served as a test of linkage. No evidence of linkage was detected in any of the crosses (data not presented).

\section{Discussion}

The Topiary mutant has a complex of traits that distinguishes it from other bean mutants. Most prominent are shiny, dark green leaves on a shortened rachis, petiolules, and petioles that cause overlapping leaflets. These leaflets are thicker, more brittle and smaller than the leaflets of normal plants. The Topiary mutant begins blooming at a lower node, and proceeds to bloom in both directions, but mostly upward from that node. The terminal bud is reproductive rather than vegetative as is normally found in indeterminate lines. This is a new form of determinacy in common bean.

In crosses of Topiary to lines carrying $o l$ and $d g s$ for tests of allelism, the double recessive class was not observed. We suspect that epistasis masks expression of Topiary in the double recessive. Intuitively, we would expect Topiary to be epistatic to both $o l$ and $d g s$, however, the small population size did not allow us to differentiate between 9:3:4 and 9:4:3 segregation ratios. These results indicated that the Topiary mutant is not allelic to ol or $d g s$. We propose the designation top as the gene symbol for this mutant. The gene symbol top is an abbreviation for Topiary describing the neat, compact appearance of this mutant.

Short petiole or petiolule traits have been studied in soybean [Glycine max (L.) Merr.] (Cary and Nickell, 1999; Kilen, 1983; You et al., 1998). The short-petiole trait of breeding line D761609 was inherited as a single recessive gene (Kilen, 1983). You et al. (1998) reported a new short-petiole mutant in the breeding line NJ90L-1SP. Genetic analysis showed a single locus inheritance when NJ90L-1SP was crossed to 'Nannong 86-4'. However, two-locus inheritance was found when NJ90L-1SP was crossed to a sister line, NJ90L-2. Tests of allelism conducted between the breeding lines NJ90L-1SP and D76-1609 indicated nonallelism because all $\mathrm{F}_{1}$ plants had long petioles. The gene symbol $l p s_{1}$ was

Table 5. $\mathrm{F}_{1}$ and $\mathrm{F}_{2}$ tests of allelism between Topiary and ol, or $d g s$ common bean mutants.

\begin{tabular}{|c|c|c|c|c|c|c|}
\hline \multirow[b]{2}{*}{$\operatorname{Cross}^{2}$} & \multicolumn{3}{|c|}{ No. of plants } & \multirow{2}{*}{$\begin{array}{c}\text { Expected } \\
\text { ratio }^{y}\end{array}$} & \multirow[b]{2}{*}{$\chi^{2}$} & \multirow[b]{2}{*}{$P$} \\
\hline & Normal $\mathrm{Ol} / \mathrm{Dgs}$-Topiary $\mathrm{Ol} / \mathrm{Dgs}$ & Normal ol/dgs & Topiary $o l / d g s$ & & & \\
\hline Topiary $\mathrm{X}$ ol $\mathrm{F}_{1}$ & 36 & 0 & 0 & 1:0:0:0 & 0.0 & 1.0 \\
\hline Topiary $\mathrm{x} d g s \mathrm{~F}_{1}$ & 36 & 0 & 0 & $1: 0: 0: 0$ & 0.0 & 1.0 \\
\hline Topiary $\times$ ol $\mathrm{F}_{2}$ & 24 & 17 & 0 & $9: 3: 3: 1$ & 2.240 & 0.33 \\
\hline Topiary $\mathrm{x} d g s \mathrm{~F}_{2}$ & 22 & 16 & 0 & $9: 3: 3: 1$ & 3.051 & 0.22 \\
\hline Combined & 46 & 33 & 0 & $9: 3: 4$ & 4.698 & 0.10 \\
\hline & & & & $9: 3: 3$ & 11.767 & 0.003 \\
\hline
\end{tabular}

${ }^{\mathrm{z}}$ Cross and reciprocal combined.

${ }^{y}$ For a 9:3:4 ratio, we assume that double recessive individuals are counted in the Normal ol/dgs class. The hypothesis for a 9:3:3 ratio is that the double recessive class is missing. 
proposed for the recessive gene carried by D76-1609 and $l p s_{2}$ was proposed for the recessive gene discovered in NJ90L-1SP.

Cary and Nickell (1999) reported a mutant in the soybean line LN89-3502TP in which petiolules of the plant were shorter than normal and leaflet margins curled uniformly upward forming a cupped-shaped leaf. The trait was controlled by a single gene showing incomplete dominance, and was given the gene symbol $l c$.

The Topiary mutant arose spontaneously from an Andean x Mesoamerican cross (Gepts, 1988). Several mutations affecting growth habit, including multiple primary leaves, dwarf plant habit, and an aphyllus mutant (Lamprecht, 1958), have been observed from such crosses (J.R. Myers, unpublished data). The Andean and Mesoamerican centers of origin are separated by about $4000 \mathrm{~km}$, which has allowed populations to diverge genetically. While not separate biological species, certain genetic incompatibilities such as dwarf lethal genes (Gepts, 1988) are manifested upon crossing. The Topiary mutant may represent another example of this AndeanMesoamerican incompatibility.

In other plant species, mutations in the cytokinin and auxin pathways can cause abnormalities similar to those seen in Topiary (Dean, 1998; Estruch et al., 1993; Felix et al., 1996; Levy and Spena et al., 1991; Strabala et al., 1996). No mutant has been described that shows the complete set of abnormalities of Topiary although the Waldmeister mutant in Arabidopsis thaliana (L.) Heynh. converts indeterminate inflorescences into determinate ones as well as affecting leaf shape (Felix et al., 1996). The Topiary mutant may represent a mutation in a regulatory gene involved in fundamental metabolic processes, with effects on possibly more than one biochemical pathway.

Singer et al. (1990) studied a determinate mutant (det) of pea (Pisum sativum $\mathrm{L}$ ). They reported that the apparent terminal flower arises from an axillary meristem. The terminal meristem senesces and differentiates trichomes, forming a rudimentary stub in the same manner as axillary meristems of conventional (Det) plants. Thus, the effect of the det gene on inflorescence architecture results from early apical arrest rather than conversion of terminal meristem. To our knowledge, no studies in bean have examined the ontogenesis of determinacy conditioned by fin. We also do not know if Topiary conditions determinacy in a manner similar to det in peas.

The genetic merit of this mutant needs to be investigated using several breeding approaches. Because the Topiary mutant has a single stem, closer row spacing may be achieved for higher planting populations. However, some of the other pleiotropic effects of this recessive gene may be detrimental to economic use of the trait for common bean improvement. Overlapping leaflets could make favorable conditions for white mold development. If most flowers protrude beyond the foliage, this could affect pod set in hot climates and reduce yield. These effects need to be determined. Placed into an upright background with pod placement off the ground, Topiary may provide a plant type suitable for direct harvest. We do not know the effects of the gene for Topiary on yields in comparison to cultivars with normal growth habit. The transfer of Topiary into upright, near isogenic backgrounds and comparison to commercial cultivars is a goal of our program.

\section{Literature Cited}

Baggett, J.R., W.A. Frazier, and G.W. Varseveld. 1981. Oregon 91 green bean. HortScience 16:230.

Bliss, F.A. 1980. Common bean, p. 273-284. In: W.R. Fehr and H.H.
Hadley (eds.). Hybridization of crop plants. Amer. Soc. Agron.-Crop Sci. Soc. Amer., Madison, Wisc.

Burke, D.W. 1982. Registration of red mexican beans Rufus, NW-59 and NW-63. Crop Sci. 22:685-686.

Cary, T.R. and C.D. Nickell. 1999. Genetic analysis of a short-petioluletype soybean, LN89-3502TP. J. Hered. 90:300-301.

Coyne, D.P. 1980. Modification of plant architecture and crop yield by breeding. HortScience 15:244-247.

Dean, L.L. and M.J. LeBaron. 1964. Red mexican beans UI-36 and UI-37. Idaho Agr. Expt. Sta. Bul. 429.

Debouck, D.G., H. Rubiano, and M.C. Menendez. 1988. Determinate climbers among Argentinean materials of Phaseolus vulgaris L. Annu. Rpt. Bean Improvement Coop. 31:189-190.

Estruch, J.J., A. Granell, G. Hansen, E. Prinsen,P. Redig, H. Van Onckelen, Z. Schwarz-Sommer, and A. Spena. 1993. Floral development and expression of floral homeotic genes are influenced by cytokinins. Plant J. 4:379-384.

Everitt, B.S. 1977. The analysis of contingency tables. Wiley, New York. Felix, G., T. Altmann, U. Uwer, A. Jessop, L. Willmitzer, and P-C. Morris. 1996. Characterization of waldmeister, a novel developmental mutant in Arabidopsis thaliana. J. Expt. Bot. 47:1007-1017.

Fernandez, F., P. Gepts, and M. Lopez. 1986. Stages of development of the commonbean plant. Centro Internacional de Agricultura Tropical (CIAT), Cali, Colombia.

Frazier, W.A. and D.W. Davis. 1966. Inheritance of dark green savoy mutant. Annu. Rpt. Bean Improvement Coop. 9:22.

Gepts, P. 1988. A middle American and an Andean common bean gene pool, p. 375-392. In: P. Gepts (ed.). Genetic resources of Phaseolus beans. Kluwer Academic Publ., Dordrecht, The Netherlands.

Kelly, J.D. and M.W. Adams. 1987. Phenotypic recurrent selection in ideotype breeding of pinto beans. Euphytica 36:69-80.

Kilen, T.C. 1983. Inheritance of a short petiole trait in soybean. Crop Sci. 23:1208-1210.

Lamprecht, H. 1958. Weitere studien über die aphyllus-mutante von Phaseolus vulgaris. Agr. Hort. Genet. 16:103-111.

LeBaron, M.J. 1959. UI 35 Red mexican bean. Idaho Agr. Expt. Sta. Bul. 295.

Levy, Y.Y. and C. Dean. 1998. The transition to flowering. Plant Cell 10:1973-1989.

Mather, K. 1951. The measurement of linkage in heredity. Methuen and Co., Ltd., London.

Myers, J.R. 1992. Values and use of the National Dry Bean Nurseries. Annu. Rpt. Bean Improvement Coop. 35:1-2.

Myers, J.R., R.E. Hayes, and J.J. Kolar. 1991. Registration of 'UI 906' black bean. Crop Sci. 31:1710.

Nagata, R.T. and M.J. Bassett. 1984. Characterization and inheritance of gamma ray induced mutations in common bean. J. Amer. Soc. Hort. Sci. 109:513-516.

Ramsey, F.L. and D.W. Schafer. 1997. The statistical sleuth. Thomson Publ. Co., Belmont, Calif.

Singer, S.R., L.P. Hsiung, and S.C. Huber. 1990. Determinate (det) mutant of Pisum sativum (Leguminosae: Papilionoideae) exhibits an indeterminate growth pattern. Amer. J. Bot. 77:1330-1335.

Smith, J.A. 1996. Harvest, p. 32-39. In: H.F. Schwartz, D.S. Nuland, and G.D. Franc (eds.). Dry bean production and pest management. Coop. Ext. Resource Ctr., Colo. Reg. Bul. 562A.

Spena, A., E. Prinsen, M. Fladung, S.C. Schulze, and H. Van Onckelen. 1991. The indoleacetic acid-lysine synthetase gene of Pseudomonas syringae subsp. savastanoi induces developmental alterations in transgenic tobacco and potato plants. Mol. Gen. Genet. 227:205-212.

Strabala, T.J., Y.H. Wu, and Y. Li. 1996. Combined effects of auxin transport inhibitors and cytokinin: Alternations of organ development in tobacco. Plant Cell Physiol. 37:1177-1182.

You, M., T. Zhao, G. Junyi, and Y. Yang. 1998. Genetic analysis of short petiole and abnormal pulvinus in soybean. Euphytica 102:329-333. 